\section{Rasio Neutrofil dan Limfosit (NLCR) Sebagai Faktor Risiko Terjadinya Infeksi Bakteri di Ruang Rawat Anak RSUP Sanglah Denpasar}

IM Yullyantara Saputra, W Gustawan, MG Dwilingga Utama, BNP Arhan

RSUP Sangla

Latar belakang. Rasio neutrofil dan limfosit (NLCR) memiliki potensi sebagai prediktor bakteremia pada pasien dengan infek

Tujuan. Untuk mengetahui hubungan rasio neutrofil dan limfosit (NLCR) dengan kejadian infeksi bakteri.
letode. Seb 016 hingga Maret 2018. Data yang diambil adalah usia, jenis kelamin, kadar WBC, Neutrofil, limfosit, monosit, platelet, dan kult

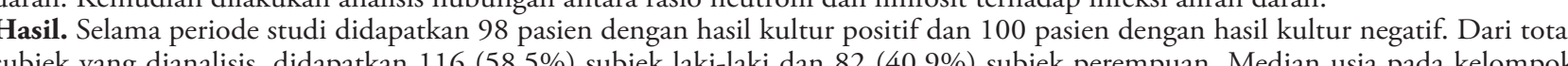

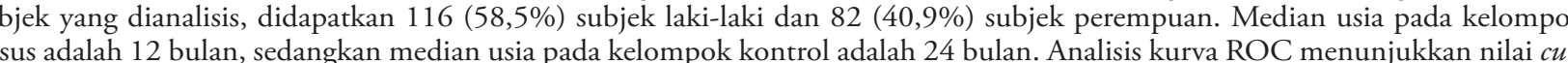
off optimal untuk NLCR adalah 4,67. Rasio odd untuk hubungan antara NLCR dengan kejadian infeksi bakteri adalah 3,24 (95\%

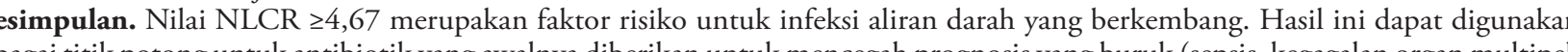
sebagai titik potong untuk antibiotik yang awalny
dan kematian). Sari Pedliatri 2019;20(6):354-9

Kata kunci: rasio neutrofil terhadap limfosit, infeksi bakteri, faktor risiko

Neutrophil to Lymphocyte Count Ratio (NLCR) as a Risk Factor for Blood Stream Infection in Pediatric Ward Sanglah Hospital Denpasar

IM Yullyantara Saputra, W Gustawan, MG Dwilingga Utama, BNP Arhan

Background. Neutrophil to lymphocyte count ratio (NLCR) is a potential predictor of bacteremia in patients with community
acquired infection. The incidence of bacteremia, which defined as the presence of viable bacteria in bloodstream, is approximately $1 \%$. The mortality rate reaches $25 \%-30 \%$ and increases up to $50 \%$ in patients with severe sepsis.

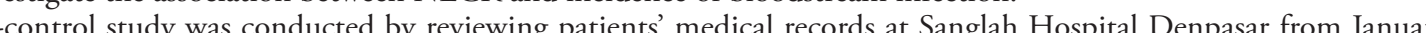
2016 to March 2018. The variables analyzed in this study include age, sex, total leukocyte, neutrophil, lymphocyte, monocyte, platel counts, and blood culture results. Association analysis was subsequently conducted for NLCR and incidence of bacterial infection. Result. Within the study period, a total of 98 subjects with positive blood culture and 100 subjects with negative blood culture wer ( 467. The Odds ratio for association between NLCR and incidence of bacterial infection was 3.24 (95\% CI 1.74 - 5.92) and adjusted dds ratio was $3.49(95 \%$ CI $1.83-6.64)$

Conclusion. NLCR of $\geq 4.67$ is a risk factor of developing bloodstream infection. This result can be used as the cut-off value for hitiating antibiotic therapy that is previously used for preventing worse outcomes (sepsis, multiple organ failure, and mortality).

Keywords: neutrophil to lymphocyte count ratio, bacterial infection, risk factor Alamat korespondensi: IM Yullyantara Saputra. Bagian/SMF Ilmu Kesehatan Anak Fakultas Kedokteran Universitas Udayana/ RSUP
Sanglah. Email: yulygantaras.sputru@egmailcom
$\mathrm{R}$ sio neutrofil dan limfosit (neutrophil to ameter laboratorium yang berpoten paja prediktor infeksi aliran darah/ akteremia pada pasien dengan dugaan infeksi yan didapat dari masyarakat. Insiden bakteremia yang didefinisikan sebagai adanya pertumbuhan bakteri hidup dalam aliran darah mencapai sekitar $1 \%$ dari otal admisi ke rumah sakit. Pasien denoan infeksi aliran darah memiliki luaran yang jauh lebih buruk dibandingkan dengan kontrol dengan hasil kultur darah negatif sehingga tatalaksana segera aka memperbaiki luarn paien. Infeksi hera aka menyebabkan in coman. Demam merupakn manifestas yang dengan diteman. Dem etapi hanya sedikit pasen yang menunuklan hasil kultur positif. ${ }^{1}$

Populasi sel darah putih pada pasien imunokompeten (monosit, limfosit, dan neutrofil) berperan penting dalam respons inflamasi sistemik terhada infeksi berat. Fase hiperdinamik pada awal infeks ditandai dengan status proinflamasi yang dimedias leh neutrofil, makrofag, dan monosit yang diikuti pelepasan sitokin inflamasi, seperti tumor necrosis factor- $\alpha$ (TNF- $\alpha$ ) dan interleukin (IL) 1 dan IL6. Respon inflamasi sistemik ini dikaitkan dengan penekanan apoptosis neutrofil yang meningkatkan pembunuhan patogen yang dimediasi oleh neutrofil sebagai bagian dari respons imun bawaan, tetapi jug dapat menyebabkan kenusakan jaringan. Neutrofil selama inflamasi sistemik disebabkan oleh demarginasi neutrofil, penundaan apoptosis neutrofil, dan stimula i sel punca oleh faktor pertumbuhan (G-CSF). Pada saat yang bersamaan, apoptosis limfosit pada kelenjar timus dan limpa meningkat. Hal ini dapat menyebabka penekanan sistem imun, disfungsi organ multipel, an kematian. Depresi imunitas selular bawaa ditandai dengan penurunan persisten pada kadar sel $\mathrm{TCD}^{+}$dan peningkatan sel $\mathrm{TCD} 8^{+}$. Rasio sel $\mathrm{TCD} 4^{+}$ $\mathrm{TCD}^{+}$yang kurang dari 1 merupakan prediktor yan baik untuk imunosupresi dan risiko tinggi SIRS dan kegagalan multiorgan. ${ }^{2}$

Rasio hitung neutrofil dan limfosit (NLCR) dapat dihitung dengan mudah dan dapat didapatkan dengan cepat dari pemeriksaan darah lengkap sebagi ba ontuk mengidentifikasi pasien-pasien yang berisik

mengalami bakteremia dan indikasi pemberian terapi

Sari Pediatri, Vol. 20, No. 6, April 2019 antibiotik. De Jager $\mathrm{dkk}^{2}$ mengevaluasi performa NLCR dan penanda infeksi hinnya dalam mempre diksi bakteremia pada orang dewasa yang datang ke instalasi gawat darurat di Belanda. Sembilanpuluh dua kohort pasien dengan dugaan bakteremia yang didapar dari komunitas dengan hasil kultur darah positif dibandingkan dengan 92 kontrol yang sesuai dengan hasil kultur negatif. Tidak ditemukan perbedaan yang bermakna dalam hitung leukosit dan neutrofil antara kedua kelompok. Namun, kelompok infeksi memiliki jumlah limfosit kadar C-reactive protein (CRP) dan NLCR yang lebih

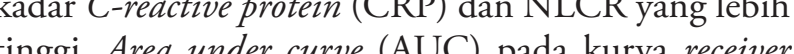
inggi. Area under curve (AUC) pada kurva receiver operating characteristic (ROC) untuk NLCR sebesar

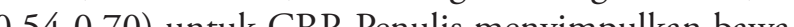
0,53 (IK 0,66-0,80) dire CRediktor bakteremia yang lebih baik dibandingkan CRP, hitung
leukosit, dan neutrofil.,33

Hingga saat ini, belum ada data mengenai dubung antara NLCR dan insidensi infeksi aliran darah yang telah dilakukan di Indonesia, khususnya hubungan antara NLCR dan infeksi aliran darah.

\section{Metode}

Studi ini merupakan studi retrospektif yang dilakuka dengan menggunakan desain kasus-kontrol berbasis rumah sakit. Studi ini dilakukan di Ruang Rawat Inap Pediatrik Rumah Sakit Sanglah, Denpasar. Pengambilan sampel dilakukan mulai 1 Januari 2016 hingga 31 Mare 2018. Kriteria inklusi yang digunakan, antara lain, (1) pasien yang dirawat di ruang rawat inap pediatrik RSUP Sanglah, Denpasar; (2) pasien berusia antara 0 hingga 18 tahun; (3) tidak ada riwayat pemberia antibiotik sebelum admisi ke rumah sakit. Sementan kriteria eksklusi, antara lain, pasien dengan penyakit hematologi dan onkologi, defek jantung kongenital, riwayat penyakit imunologis, penyakit autoimun, dan pasien yang mendapatkan terapi kortikosteroid jangk panjang. Pengambilan sampel dilakukan dengan teknik acak konsekutif (consecutive random sampling) melalui tinjauan rekam medis. Data yang dicatat, meliputi data demografik, seperti usia dan jenis kelamin; rasio hitung neutrofil dan limfosit dan insiden infeksi hakteri dikoutrofil dan limfosit dan insiden infeksi perhitungan jumlah sampel menurut desain studi 
yang digunakan, didapatkan jumlah sampel minimal 80 subjek untuk masing-masing kelompok kasus dan kelompok kontrol.

Analisis data dilakukan dengan perangkat lunak SPSS versi 20.0. Analisis deskriptif dilakukan untuk mendeskripsikan karakteristik populas studi. Selanjutnya dilakukan analisis asosiasi untuk mengetahui hubungan antara NLCR dan infeksi aliran darah. Analisis regresi logistik dilakukan denga penyesuaian terhadap variabel lain untuk menila hubungan antara setiap varibel independen denga insidensi infeksi aliran darah. Nilai $\mathrm{p}<0,05$ diangep bermakna secara statistik.

\section{Hasil}

Karakteristik populasi studi

Pada periode antara 1 Januari 2016 dan 31 Mare 2018 , terdapat 98 pasien dengan hasil kultur darah positif dan 100 pasien negatif yang disertakan dalam studi. Dari total subjek penelitian, $116(58,5 \%)$ subjek merupakan laki-laki dan $82(40,9 \%)$ subjek

merupakan perempuan. Pada kelompok kontrol, 66 $(66,7 \%)$ subjek merupakan laki-laki dan $33(33,3 \%)$ perempuan. Sementara pada kelompok kasus, 50 (51\%) subjek merupakan laki-laki dan $48(49 \%)$ perempuan. Median usia untuk kelompok kasus adalah 12 bulan, sedangkan kelompok kontrol adala 24 bulan. Karakteristik subjek penelitian tertera pad Tabel 1.

Median rasio neutrofil dan limfosit (NLCR) pad elompok kasus adalah 5,64 (0,55-50,23). Berdasarka kurva ROC, nilai cut-off optimal untuk NLCR adalah 4,67 yang mentailkan sensitivitas 0,54 do spesifisitas 0,81. Nilai AUC untuk NLCR a untuk memprediksi infesi bakteri pad 198 s.7. enelition. Kara ROC tertera pa Ga 1 . Odds pir $(\mathrm{OR})$ yang tion 1,24 deng $95 \%$ IK $1,74-5,92$

Mengingat distribusi data yang tidak normal, kam en variabel usia dan jenis kelamin dengan menggunakan analisis regres K 1,839-6,644; Tabel 3).

Tabel 1. Karakteristik dasar populasi studi ( $\mathrm{N}=198)$

\begin{tabular}{lccc}
\hline Variabel & \multicolumn{2}{c}{ Kelompok (Median) } & \multirow{2}{*}{ Nilai p } \\
\cline { 2 - 3 } & \multicolumn{1}{c}{ Kasus } & Kontrol & \\
\hline Usia (median) & $12(1-204$ bulan $)$ & $24(1-168$ bulan $)$ & $<0,001$ \\
Jenis kelamin $N(\%)$ & & & \\
$\quad$ Laki-laki & $50(51)$ & $66(66,7)$ & 0,026 \\
$\quad$ Perempuan & $48(49)$ & $34(33,3)$ & \\
Sel darah putih & $12,47(0,07-91,9)$ & $13,21(0,23-46,01)$ & 0,945 \\
Neutrofil & $10(0,1-81,4)$ & $7,97(0,15-45,53)$ & 0,172 \\
Limfosit & $2,0(0,1-15,0)$ & $2,9(0,01-23,8)$ & $<0,001$ \\
Monosit & $0,88(0,6-1,26)$ & $1,27(0,22-1,70)$ & 0,007 \\
Trombosit & $317,20(295,61-389,46)$ & $213(105,48-294,47)$ & 0,019 \\
Total N & $98(100 \%)$ & $100(100 \%)$ & \\
& & &
\end{tabular}

abel 2. Rasio hitung neutrofil dan limfosit (NLCR) sebagai faktor risiko untuk infeksi aliran darah

\begin{tabular}{|c|c|c|c|c|c|}
\hline \multirow[t]{2}{*}{ Variabel } & \multicolumn{2}{|c|}{ Kelompok } & \multirow{2}{*}{$\begin{array}{l}\text { Odds ratio } \\
\text { (OR) }\end{array}$} & \multirow{2}{*}{$95 \%$ IK } & \multirow{2}{*}{ Nilai p } \\
\hline & Kasus & Kontrol & & & \\
\hline $\begin{array}{l}\text { NLCR } \\
>4.67\end{array}$ & & & & & \\
\hline $\begin{array}{l}\geq 4,67 \\
<4,67\end{array}$ & $\begin{array}{l}48(41,8 \%) \\
50(58,2 \%)\end{array}$ & $\begin{array}{l}23(20 \%) \\
77(80 \%)\end{array}$ & 3,24 & $1,74-5,92$ & $<0,001$ \\
\hline Total N & 98 (100\%) & $100(100 \%)$ & & & \\
\hline
\end{tabular}

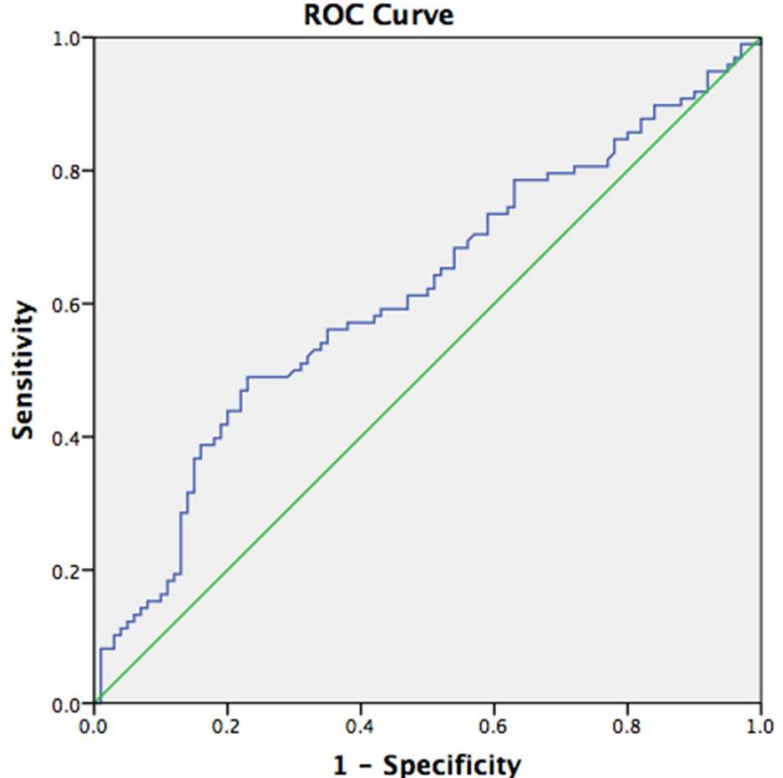

Gambar 1. Kurva ROC untuk rasio neutrofil dan limfosit

Tabel 3. Adjusted odds ratio untuk usia dan jenis kelamin

Variabel

NLCR $\geq 4,67$

Laki-lak

Adjusted OR

3,496

$95 \%$ IK

$1,83-6,64$

$1,002-1,016$

Nilai $\mathrm{p}$

$<0,00$

0,009

\section{Pembahasan}

Diagnosis dini dan inisiasi pemberian antibioti spektrum luas berdampak perbaikan luaran pada pasie dengan bakteremia. Oleh sebab itu, pengambilan sampel darah untuk pemeriksaan kultur bakteri merupakan standar pemeriksaan yang harus dilakuka sebelum melakukan pemberian terapi antibiotik. Akan tetapi, demam dan inflamasi sistemik tidak mengindikasikan bakteremia pada seluruh kasus. Pada sisi lain, terdapat pula kemungkinan terjadi dampa buruk pasca pemberian terapi antibiotik, seperti reaksi alergi, infeksi Clostridium difficile dan munculnya galur bakteri yang resisten terhadap terapi antibiotik. Saat ini, masih belum ada biomarka yang ideal untuk mendiagnosis sepsis atau bakteremia, dan pemeriksaan baku emas — isolasi dan identifikasi bakteri di dalam aliran darah. Diagnosis sepsis mungkin tertunda atau bahkan tidak dapat dilakukan pada situasi klinis (a)

Pada studi kami, berdasarkan data dasar studi, pada periode studi antara 1 Januari 2016 dan Maret 2018, terdapat 198 subjek. Sembilan puluh delapan subjek menunjukkan hasil kultur darah positif (bakteremia) yang kemudian ditetapkan sebagai kelompok kasus dan 100 subjek dengan hasil kultur darah negatif sebagai kelompok kontrol. Pada kelompok kasus, 50 (51\%) subjek laki-laki dan $48(49 \%)$ perempuan. Sementara itu, pada kelompok kontrol, $66(66,7 \%)$ subjek laki-laki dan $34(33,3 \%)$ perempuan. Tidak terdapat perbedaan yang bermakna antara kedua kelompok jenis kelamin. Akan tetapi, terdapat kecenderungan bahwa laki-laki memiliki risiko yang lebih rendah untuk mengalami bakteremia. Median usia kelompok kasus dan kontrol adalah 12 dan 24 bulan. Hasil ini sesuai dengan studi 
sebelumnya yang dilakukan oleh Randolph dkk yang menyatakan bahwa pada usia 2 tahun, respons imun bawaan dan didapat sudah mendekati tingkat respons imun pada orang dewasa yang sehat. Hasil akhir fungsi imun kurang kompeten, bayi cenderung lebih rentan untuk mengalami infeksi berat yang disebabkan oleh berbagai organisme, khususny virus dan bakteri berkapsul. Kerentanan terhadap infeksi virus yang berat paling jelas didapatkan pad anak berusia kurang dari 2 tahun, yang sebagin disebabkan karena replikasi virus yang tidak dikana akibat rendahnya produksi IFN- $\gamma$ dan kurangnya respons sel T sitotoksik 6,10

Pada studi kami, median rasio neutrofil da Pa (0,55 - 50,23). Nilai cut-off optimul unal NLCR yang ditentkan 4,67 , 0,81 . Nihi AUC yag dide kan nilai spesifisitas 0,81. Nilai AUC yang didapatkan untuk (1) be berage baksenia (sepsis). Sen dklo di Tulk, menemuka insiden sepsis yang secara bermakna lebih tinger pada pasien dengan NLCR $>2,50$ diber pasien dengan NLCR $<2,50$. Lowsby dkk, ${ }^{5}$ di Inggris, menemukan hididen bakteremia meningkat pada NLCR $>10$ dengan nilai prediksi positif dan negatif masingmasing $0,20(0,18-0,23)$ dan $0,92(0,91-0,94)$. Akan tetapi, hasil ini tidak bermakna secara statistil. Naess dkk, ${ }^{6}$ di Norwegia, menemukan insiden sepsis yang secara bennakna lebih tinggi pada pasin dengan NLCR $\geq 12,23$. Di Indonesia, hanya ada yang dilakukan di Rumah Sakit Hasan Sadikin ole Suwarman $\mathrm{dkk}^{\gamma}$ yang melaporkan insiden sepsis dan disfungsi organ multipel yang lebih tinggi pada NLCR $\geq 5$. Hasil tersebut sependapat dengan hasil studi kami yang menemukan nilai cut-off optimal untuk NLCR sebesar 4,67. Berbeda dengan biomarka lain, NLCR merupakan parameter yang murah dan mudah didapar serta tidak membutuhkan peralatan atau instrumen pemeriksaan khusus untuk pengukuran NLCR. Sam halnya dengan prokalsitonin, perubahan pada populasi leukosit berlangsung cepat yang mencerminkan adanya peran neutrofil pada fase awal respons inflamasi dan berbagai proses yang mencetuskan stres. Respon fisiologis dari leukosit dalam aliran darah ditandai dengan adanya peningatan jumlah neutrofil dan penurunan jum limfosit. Neutrofilia disebabkan oleh demarginasi neu- trofil, penundaan apoptosis neutrofil, dan stimulasi sel punca oleh faktor pertumbuhan. Marginasi limfosit, redistribusi limfosit dan peningkatan tajam apoptosisnya merupakan mekanisme yang diduga menyebabka limfositopenia yang diamati pada kasus penyakit infeksi.

Pada studi kami, OR yang menentukan hubungan ntara rasio hitung NLCR dengan infeksi aliran darah adalah 3,24 (IK 95\% 1,74 - 5,92) dan adjusted OR 3,49 (IK 95\% 1,839 - 6,644). Rasio lebih dari 1 $(3,49)$ menunjukkan bahwa kelompok dengan NLCR lebih dari atau sama dengan nilai cut-off memiliki kemungkinan 3,5 kali lebih nilai cut-off memiliki kemungkinan 3,5 kali lebih tinggi untuk mengalam bakteremia dibandingkan dengan kelompok kontro Rasio ini dapat digunakan sebagai tanda awal infeksi pada aliran darah dan dapat mengarahkan pemberia pencega turan yang lebih buruk. Hasil ini merupaka asukan pengetahuan yang baru karena sebelumny dipeng hi

\section{Kesimpulan}

Rasio NLCR $\geq 4,67$ merupakan faktor risiko bakteremi Nilai cut-off ini dapat digunakan untuk menginisias pemberian terapi antibiotik untuk mencegah prognosi yang lebih buruk (sepsis, kegagalan organ multipel, da kematian). Durasi yang lebih lama dan jumlah sampe yang lebih besar diperlukan untuk mengonfirmasi hasil studi.

\section{Daftar pustaka}

1. Chalupa P, Beran O, Herwald H, Kaspríková N, Holub M. bacterial and viral infections. Infection 2011;39:411-7.

2. De jager CP, Wever PC, Gemen EFA, Lafeber ABN, Poll TVD, Laheij RJF. The neutrophil-lymphocyte count ratio in patients with community-acquired pneumonia. Plos one 2012;7:1-8.

Ho KM, Lipman J. An update on C-reactive protein for intensivists. Anaesth Intensive Care 2009;37:234-41.

4. Holub M, Beran O, Kasprííková N, Chalupa P. Neutrophil to lymphocyte count ratio as a biomarker of bacteria infections. Cent

5. Lowsby R, Gomes C Jarman I, dkk Neutrophil to lymphocyc count ratio as an ealy indicator of bod strem inferion the emergency department. Emerg Med J 2015;32:531-4.

6. Naess A, Nilssen SS, Mo R, Eide GE, Sjursen H. Role of neutrophil to lymphocyte and monocyte to lymphocyte ratios in diagnoses of bacterial infection in patients with fever. Infection 2017;45:299-307.

7. Nugroho A, Suwarman, Nawawi AM. Hubungan antara Rasio Neutrofil-Limfosit dan Skor Sequencial Organ Failure Assesment pada Pasien yang Dirawat diruang intensive care. Jurnal Anestesi Perioperative 2013;3:189-96
8. Randolph AG, McCulloh R. Pediatric sepsis. Virulence 2014;5:179-89.

Sen V, Bozkurt 1H, Aydogdu O, dkk. Significance of preoperative neutrophilelymphocyte count ratio on predicting postoperative sepsis after percutaneous nephrolithotomy. KJMS 2016;32:507-13.

10. Wyllie DH, Bowler IC, Peto TE. Bacteraemia prediction in emergency medical admissions: role of $\mathrm{C}$ reactive protein. J Clin Pathol 2005:58:352-6. 